\title{
Attitudes and practices of primary care physicians in Ankara about food allergy and anaphylaxis
}

\author{
Aysegul Akan ${ }^{1 *}$, Ersoy Civelek', Mustafa Erkocoglu', Celal Ozcan', Dilek Azkur ${ }^{1}$, Muge Toyran', Yasemin Gokce², \\ Tali Ozdemir², Sedat Guler ${ }^{2}$, Can Naci Kocabas ${ }^{1}$ \\ From Food Allergy and Anaphylaxis Meeting 2011 \\ Venice, Italy. 17-19 February 2011
}

\section{Background}

Because of the rise in the frequency, food allergies (FA) and consequently anaphylaxis (A) are becoming public health problems. The conciousness about prevention, diagnosis and therapy has to be improved, especially among primary care physicians (PCP).

\section{Methods}

The survey including questions and case examples about FA and was given to PCP during the 2 meetings held by Local Health Managers' Office of Ankara.

\section{Results}

Median of the age of the participants and duration of theri practice were $42.4 \pm 6.5$ and $17.0 \pm 6.4$ years. The $72.4 \%$ of participants pointed out that lower than $5 \%$ of their pediatric patients had food allergy. The $36.6 \%$ of the participants thought that FA could be completely cured with therapy, the $36.9 \%$ stated that they didn't refer the patients suspected for FA.The $73.4 \%$ defined asthma as a significant risk factor of A for the patient with FA. Egg white was the most common food allergen (85.8\%) defined by PCP and teh second common food allergen was cow's milk (67.5\%). The $4.3 \%$ of the participants had ever given a prescription of epinephrine otoinjector, $83 \%$ of them defined they know poorly about the use of epinephrine otoinjector. The $50 \%$ of PCP defined epinephrine as the first drug in a case with anaphylaxis, $60 \%$ of this group pointed out to give subcutaneously. Fifty two percent of PCP indicated that the education for FA and A in medical school was deficient.

'Ankara Hematology Onkology Children's Training and Research Hospital, Pediatric Allergy, Ankara, Turkey

Full list of author information is available at the end of the article

\section{Conclusions}

PCP have some information about FA, but they heve to be educated about practical applications about the diagnosis and management of FA and A. Otherwise we could neither know the real extent end burden of FA and A nor form right practice.

\section{Author details}

'Ankara Hematology Onkology Children's Training and Research Hospital, Pediatric Allergy, Ankara, Turkey. ${ }^{2}$ Local Health Managers' Office of Ankara, Ankara, Turkey.

Published: 12 August 2011

doi:10.1186/2045-7022-1-S1-P42

Cite this article as: Akan et al: Attitudes and practices of primary care physicians in Ankara about food allergy and anaphylaxis. Clinical and Translational Allergy 2011 1(Suppl 1):P42.
Submit your next manuscript to BioMed Central and take full advantage of:

- Convenient online submission

- Thorough peer review

- No space constraints or color figure charges

- Immediate publication on acceptance

- Inclusion in PubMed, CAS, Scopus and Google Scholar

- Research which is freely available for redistribution

Submit your manuscript at www.biomedcentral.com/submit
( Biomed Central

\section{() Biomed Central}

